$8^{\text {th }}$ International Conference on Management, Economics and

Humanities

7 - 9 December, 2018

Barcelona, Spain

\title{
Factors influencing network relationships between businesses for internationalization
}

\author{
Ehsanul Chowdhury, Agneta Sundström, Akmal Hyder \\ University of Gävle
}

\begin{abstract}
The purpose of the paper is to investigate the factors that influence network relationships between businesses for internationalization. A qualitative study based on one to one interview, workshops and focus group discussions was conducted to gather information regarding factors influencing network relationships for internationalization from four business organizations in the Gävleborg region of Sweden. Multiple case studies were developed to present the findings. The business firms have pointed out several factors that directly and indirectly influences the network relationships in case of internationalization of the business operations. This study provides businesses an understanding of the network relationships with other businesses and allows them to take measures in order to build a sustainable business network relationship with other business to ensure sustainability and internationalization. The paper is significant for two reasons. First, it presents the situation regarding the network relationships of the business organizations on the issue of internationalization. Second, this study provides insights into an unexplored area of influencing factors that influence network relationships between businesses for internationalization. This paper is qualitative and provides ideas for future research. A quantitative study can be conducted in order develop a business network model of the business for internationalization using social network analysis.
\end{abstract}

Keywords- case; Gävleborg; qualitative: sustainable; Sweden 
